\title{
Intravenous but not intragastric urogastrone-EGF is trophic to the intestine of parenterally fed rats
}

\author{
R A GOODLAD, T J G WILSON, W LENTON, H GREGORY, \\ K G McCULLAGH, AND N A WRIGHT
}

From the Cancer Research Campaign Cell Proliferation Unit, Department of Histopathology, Royal Postgraduate Medical School, Hammersmith Hospital, London, ICI, Alderley Park, Macclesfield, and G D Searle, High Wycombe, Bucks

SUMmARY The effects of $\beta$-urogastrone/human epidermal growth factor (URO-EGF) on intestinal epithelial cell proliferation were studied in rats in which intestinal cell proliferation had been reduced to a steady state basal level, by maintaining the rats on total parenteral nutrition. The accumulation of arrested metaphases over a two hour time period was determined in a dose response study. Increasing doses of URO-EGF progressively raised the two hour collection of metaphases and intestinal weights. Intravenous infusion of URO-EGF was also effective in restoring cell proliferation when it was infused after the intestine had become hypoproliferative. $\beta$-urogastrone/human epidermal growth factor administered through an intragastric cannulae thrice daily had no significant effect on intestinal weight or crypt cell production rate or metaphase collection. It is proposed that one of the in vivo actions of urogastrone-epidermal growth factor is the maintenance of gastrointestinal growth and that this occurs through a systemic rather than a luminal mechanism.

A physiological role for the polypeptide $\beta$-urogastrone-epidermal growth factor (URO-EGF) has yet to be established despite the considerable interest shown in the in vitro actions of URO-EGF. The location of the main sites of production of URO-EGF in the salivary glands and Brunners glands of the duodenum of man' and the rat, ${ }^{2}$ however, might suggest that URO-EGF may have a role in the maintenance of gastrointestinal homeostasis.

$\beta$-urogastrone (human epidermal growth factor) is a natural human polypeptide which has similar chemical, physical, and physiological properties to rat and mouse EGF. ${ }^{3+}$ While the growth promoting actions of URO-EGF in vitro are well characterised," its role in vivo is uncertain: in the foetus and newborn animal, URO-EGF stimulates the proliferation and differentiation of the epidermis, maturation of the pulmonary epithelium and accelerates the healing of

Address for correspondence: Dr R A Goodlad, Department of Histopathology, Royal Postgraduate Medical School, Hammersmith Hospital, Ducane Road, London, W12.

Received for publication 16 September 1986 corneal epithelium. ${ }^{5} \beta$-urogastrone/human epidermal growth factor also stimulates the proliferation and maturation of the neonatal intestine, ${ }^{6-8}$ where it also increases the activity of intestinal ornithine decarboxylase, ${ }^{9}$ an enzyme associated with the initiation of cell proliferation." The presence of URO-EGF in a variety of body fluids, including saliva, plasmas and milk," its production by the salivary and Brunners glands, ${ }^{12}$ the reports of a trophic action of saliva on the intestine, ${ }^{1213}$ the demonstration of URO-EGF receptors in intestinal epithelial cells, ${ }^{1+15}$ and the reported cytoprotective effects on the duodenal mucosa ${ }^{16}$ all suggest that it has a role in the control of gastrointestinal homeostasis other than its ability to inhibit gastric acid secretion. ${ }^{17}$

It has been reported that the injection of UROEGF into rodents increases the incorporation of tritiated thymidine into DNA throughout the gastrointestinal tract, ${ }^{18} 19$ only in the stomach ${ }^{20}$ or only in starved animals. ${ }^{21}{ }^{22}$ It has also been reported that URO-EGF stimulates gastrointestinal growth in 
undernourished young rats. ${ }^{23} \mathrm{~A}$ study of the short term effects of URO-EGF administration using the more robust ${ }^{245}$ stathmokinetic method, ${ }^{26}$ showed a trophic effect which was only observed in some of the intestinal sites studied and depended on the time after injection; however, this study used starved rodents which were not in a steady state of cell proliferation.

A more suitable model of the hypoplastic intestine exists in the rat maintained by isocaloric total parenteral nutrition (TPN), ${ }^{27}$ which is generally agreed to be the pertinent system for the study of effects of humoral factors on the intestine ${ }^{28}$ as the intestine of the TPN rat is in a steady state, basal level of proliferation, with the direct and indirect effects of food (luminal nutrition) ${ }^{29}$ being abolished, and the effects of endogenous secretions considerably reduced.

We have used such a model to show that relatively low doses of URO-EGF, which should not alter acid secretion, can significantly increase intestinal epithelial cell proliferation in TPN rats. ${ }^{30}$ This model was used to further investigate the effects of recombinant URO-EGF on cell proliferation in the gastrointestinal tract. The first experiment reported in this paper investigated the effects of intravenous URO-EGF in a dose response study. The second experiment investigated the time course of the effects of URO-EGF when given after the intestine had atrophied (intervention). The effects of the intragastric administration of URO-EGF on crypt cell production rate and metaphase collection were also investigated.

\section{Methods}

\section{ANIMALS}

Male $200 \mathrm{~g}$ Wistar rats (Olac Ltd, Blackthorn, Oxon, UK) were housed individually in wire bottomed Perspex cages. The rats had constant access to tap water and were subjected to a 14 hour light, 10 hour dark schedule. The rats were maintained on the respective treatments for 10 days, unless stated otherwise. Before the experiments the rats were maintained on a pelleted diet, Labshure PRD (Labshure Ltd, Poole, Dorset, UK).

$\beta$-UROGASTRONE/HUMAN EPIDERMAL GROWTH FACTOR

The URO-EGF was recombinant polypeptide (supplied by ICI and G D Searle) derived from the expression of a synthetic gene in $E$ coli $^{31}$ and purified to $>97 \%$ by tryptic digestion and purification as judged by amino acid analysis, HPLC in two systems and by acrylamide gel electrophoresis. ${ }^{31}$ It had the same amino acid sequence as natural human URO-
EGF ${ }^{32}$ The biological activity of the cloned UROEGF was identical to that of natural URO-EGF purified from human urine in its ability to inhibit gastric acid secretion, its mitogenicity to cultured fibroblasts,${ }^{32}$ its binding to EGF receptors, and it had identical radioimmunoassay standard curves to URO-EGF purified from human urine. ${ }^{33}$

In the dose response study the rats were maintained by total parenteral nutrition (TPN), and URO-EGF was infused with the diet to give a daily intake of $0,3,15,60$ and $300 \mu \mathrm{g} / \mathrm{rat} / \mathrm{day}(15 \mu \mathrm{g} / \mathrm{rat} /$ day was the dose used in our earlier study ${ }^{30}$ and all except the highest dose should be within the range quoted for rodent EGF. ${ }^{34}$ In the intragastric infusion studies URO-EGF was given at $800 \mathrm{~h}, 1600 \mathrm{~h}$ and $2400 \mathrm{~h}$. The daily doses used were 15,150 , and $300 \mathrm{mg} / \mathrm{rat} /$ day.

B-UROGASTRONE/HUMAN EPIDERMAL GROWTH FACTOR

$\beta$-urogastrone/human epidermal growth factor was measured by standard radioimmunoassay technique. Antisera to pure $\beta$-urogastrone was raised in rabbits. The selected antiserum (1124) bound $50 \%$ of ${ }^{125}$ Ilabelled urogastrone at a final dilution of 1 in 80000 . ${ }^{125}$ I-labelled URO-EGF was prepared by the iodogen method and purified by reverse phase HPLC. The assay detected changes of $2 \mathrm{pmol} / \mathrm{l}$ between adjacent plasma samples with $95 \%$ confidence.

JUGULAR CANNULATION

Rats were anaesthetised with $0.05 \mathrm{ml}$ Hypnorm $(0.315 \mathrm{mg} / \mathrm{ml}$ fentanyl citrate and $10 \mathrm{mg} / \mathrm{ml}$ fluanisone) (Janssen Pharmaceutica - Crown Chemicals Ltd, Lamberhurst, Kent, UK) im and 0.05 ml Valium (5 mg/ml diazepam - Roche Products, Welwyn Garden City, UK) by ip injection.

The right external jugular vein of the TPN rats was cannulated with a silastic catheter, filled with 1000 IU heparin-saline solution. The cannula was tied into the jugular vein with 6-0 black surgical silk and connected through a Harvard skin button and stainless steel tether (Harvard Apparatus Ltd, Fircroft Way, Kent, UK) to a Harvard miniature fluid swivel joint.

\section{GASTRIC INTUBATION}

The gastric cannulae were made from $0.15 \mathrm{~cm}$ internal diameter $0.35 \mathrm{~cm}$ outside diameter silastic tubing (Esco Rubber Ltd, Teddington, UK). Two flanges approximately $0.3 \mathrm{~cm}$ apart were built up with silastic adhesive. The first flange was tied into the squamous stomach with a 3.0 purse string suture and the second flange was then pulled through a stab wound in the abdominal skin. The tubing was tunnelled subcutaneously to exit in the neck, just caudal to the skin button, taped to the tether and 
protected with $5 \mathrm{~mm}$ plastic cable wrap (RS Components, London, UK).

INTRAVENOUS INFUSION

The swivel joint was clamped to the top of the Perspex cages, and was connected by vinyl tubing (Portex Ltd, Hythe, Essex, UK) to a multichannel peristaltic pump (Watson Marlow Ltd, Falmouth, Cornwall, UK).

The cannulae, silastic tubing and the swivel joints were sterilised by autoclaving. The other tubing, inlet manifold (made of plastic 3-way Luer fitting taps) and connectors were sterilised by pumping detergent Hypochlorite solution through the assembled system, followed by a thorough rinse with sterile saline.

\section{TPN DIET}

The TPN diet was made up in sterile conditions in three litre infusion bags. The diet was kept in a fridge at $4^{\circ} \mathrm{C}$ and was pumped into the rats through vinyl tubing. One litre of the diet contained the following: $714 \mathrm{ml}$ Vamin glucose, $92 \mathrm{ml}$ Intralipid 20\% (Kabivitrum Ltd, Riverside Way, Uxbridge), $140 \mathrm{ml}$ dextrose $50 \%, 9 \mathrm{ml}$ Vitlipid infant (Kabivitrum), 1 vial Solvito (Kabivitrum), $20 \mathrm{ml}$ Addiphos (Kabivitrum), $12.8 \mathrm{ml} 10 \%$ calcium gluconate, $3.4 \mathrm{ml} 50 \%$ magnesium sulphate, and $8.7 \mathrm{ml} 23.4 \%$ sodium chloride. Each rat was infused with $60 \mathrm{ml} /$ day giving $1.8 \mathrm{~g} \mathrm{~N}$, as purified amino acids, which is equivalent to $11.5 \mathrm{~g}$ of first class protein; $6.0 \mathrm{~g}$ lipid; $8.5 \mathrm{~g}$ glucose and 1047 $\mathrm{kJ}(250 \mathrm{kcal})$ per kg of rat per day.

Urine was tested regularly for protein, glucose, ketone, bilirubin, blood, urobilinogen, specific gravity and $\mathrm{pH}$ with Multistix-SG (Ames Reagent Strips, Miles Laboratories Ltd, Slough, UK) and no signs of metabolic imbalance were seen in any group of rats, except those on the highest intravenous dose of URO-EGF which looked sick and had traces of blood and glucose in their urine.

\section{AUTOPSY PROCEDURE}

The rats were given $1 \mathrm{mg} / \mathrm{kg}$ vincristine sulphate (Eli Lilly, Basingstoke, UK) intravenously, and killed by injection of $12 \mathrm{mg}$ of pentobarbitone and exsanguination. The rats were weighed and the net weight of gut tissues determined. The stomach, small intestine, caecum and colon were removed, rinsed, blotted, and weighed. The stomach, caecum and samples of the small intestine and colon (as defined by their percentage length) were fixed in Carnoy's fluid. All tissue weights were expressed as a percentage of the final body weight.

TWO HOUR METAPHASE COLLECTION

Rats were killed two hours after vincristine injection.
Fixed tissue was stored in $70 \% \mathrm{v} / \mathrm{v}$ ethanol and later stained with the Feulgen reaction. The antral glands, intestinal crypts or colonic crypts were microdissected, the number of arrested metaphases in 10 crypts counted and the mean value per group calculated.

\section{CRYPT CELL PRODUCTION RATE}

Rats were killed at timed intervals after vincristine injection. The tissue was stained with the Feulgen reaction, the crypts microdissected and the number of arrested metaphases in 10 crypts counted; the mean number of metaphases per crypt was plotted against time and the slope of the line, fitted by least squares linear regression, gave the crypt cell production rate (CCPR). ${ }^{25}$

\section{VILLUS AND CRYPT LENGTHS}

These were measured in $5 \mu \mathrm{m}$ paraffin embedded transverse sections stained with haematoxylin and eosin, using a calibrated eyepiece micrometer. ${ }^{24}$ Measurements were made in three animals per group.

\section{STATISTICAL ANALYSIS}

Crypt cell production rates and weights are shown \pm standard errors. Differences between groups were tested by a two-sided Student's $t$ test for testing differences in either direction.

\section{EXPERIMENTAL DESIGN \\ Intravenous urogastrone dose response study}

The effects of 0 to $300 \mu \mathrm{g} / \mathrm{rat} / \mathrm{day}$ of URO-EGF on the two hour collection of arrested metaphases were determined in a dose response study utilising parenterally maintained rats.

\section{Intervention time course study}

The aim of this study was to investigate whether URO-EGF could reverse the hypoplasia associated with TPN once it had become established and if so to investigate the time course of the response. Rats were maintained on TPN for four days, then given $60 \mu \mathrm{g} / \mathrm{rat} / \mathrm{day}$ URO-EGF in their TPN diet and killed at six hour intervals. Proliferation was quantified by the two hour collection of arrested metaphases.

\section{INTRAGASTRIC ADMINISTRATION OF}

UROGASTRONE

The effects of intragastric infusion of URO-EGF was investigated. A tube was placed in the squamous stomach of the rats at the time of their jugular cannulation. This tube was then used to infuse UROEGF at eight hour intervals. The CCPR was measured after 10 days of daily dosing with URO$\mathrm{EGF}$ at $15 \mu \mathrm{g} / \mathrm{rat} / \mathrm{day}$. 
A further intragastric study was also carried out in which higher doses of URO-EGF (150 and $300 \mu \mathrm{g} /$ rat/day) were used, incorporating the two hour metaphase arrest method.

\section{Results}

INTRAVENOUS UROGASTRONE DOSE RESPONSE STUDY

There was a highly significant $(\mathrm{p}<0 \cdot 001)$ correlation $(r=0.997)$ between plasma URO-EGF and dose of URO-EGF administered. Plasma URO-EGF rose by $37.8 \pm 1.2 \mathrm{pg} / \mathrm{ml}$ per $\mu \mathrm{g}$ administered per rat per day.

The effects of the various doses of URO-EGF administered intravenously on intestinal wet weights are shown in Figure 1. The dotted lines show the values in rats fed a pelleted diet ad lib in our previous study. ${ }^{30}$ The lowest dose of URO-EGF had little effect, but $15 \mu \mathrm{g} / \mathrm{rat} / \mathrm{day}$ significantly increased the weights of the stomach, small intestine and colon. From $15-300 \mu \mathrm{g} / \mathrm{rat} / \mathrm{day}$ there was a logarithmic relationship between dose and weight. The weights of the high dose group increased to values above those expected in orally fed rats, with the percentage increases in weight between the high dose and the control groups being $62 \%, 92 \%, 106 \%$, and $208 \%$ for the stomach, small intestine, caecum, and colon respectively.

The two hour accumulation of metaphases in representative sites are shown in Figures 2a to d. There was no evidence of any effect at the lowest dose $(3 \mu \mathrm{g} / \mathrm{rat} / \mathrm{day})$; however, there were significant increases with the $15 \mu \mathrm{g} / \mathrm{rat} / \mathrm{day}$ group in all sites studied except the mid and distal colon. This increase in metaphase accumulation continued in a dose responsive manner in most sites. Whilst the number of metaphases in stomach and small intestine only
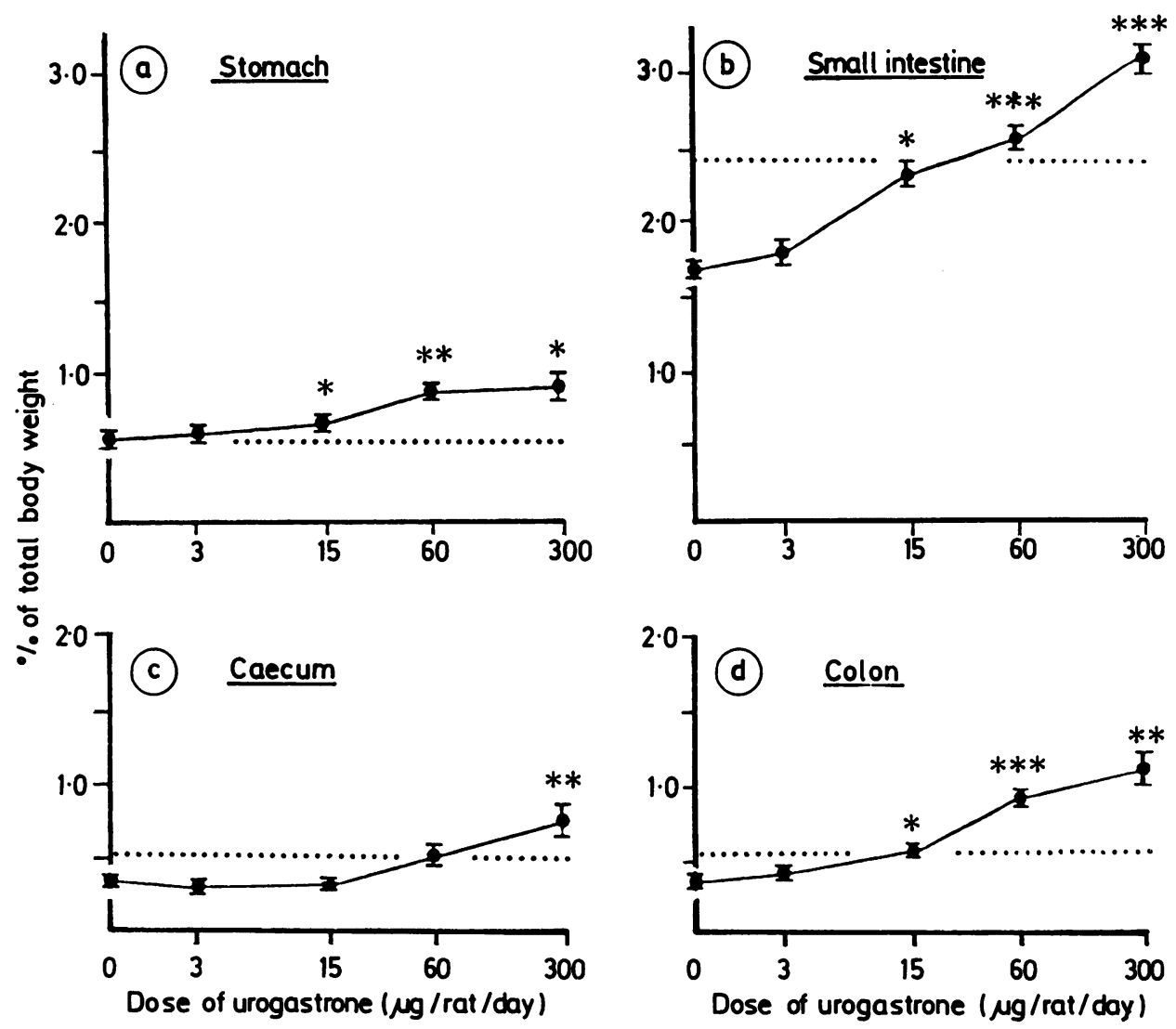

Fig. 1 Effects of 10 days intravenous infusion of various doses of urogastrone on the relative weights of the gastrointestinal tract (expressed as a percentage of total body weight). The dotted line shows the values obtained in orally fed rats. There were four animals per group. ${ }^{*}=$ significantly higher than the TPN group $p<0 \cdot 05,{ }^{* *}=$ significantly higher than the TPN group $p<0.01,{ }^{* * *}=$ significantly higher than the TPN group $p<0.001$. 

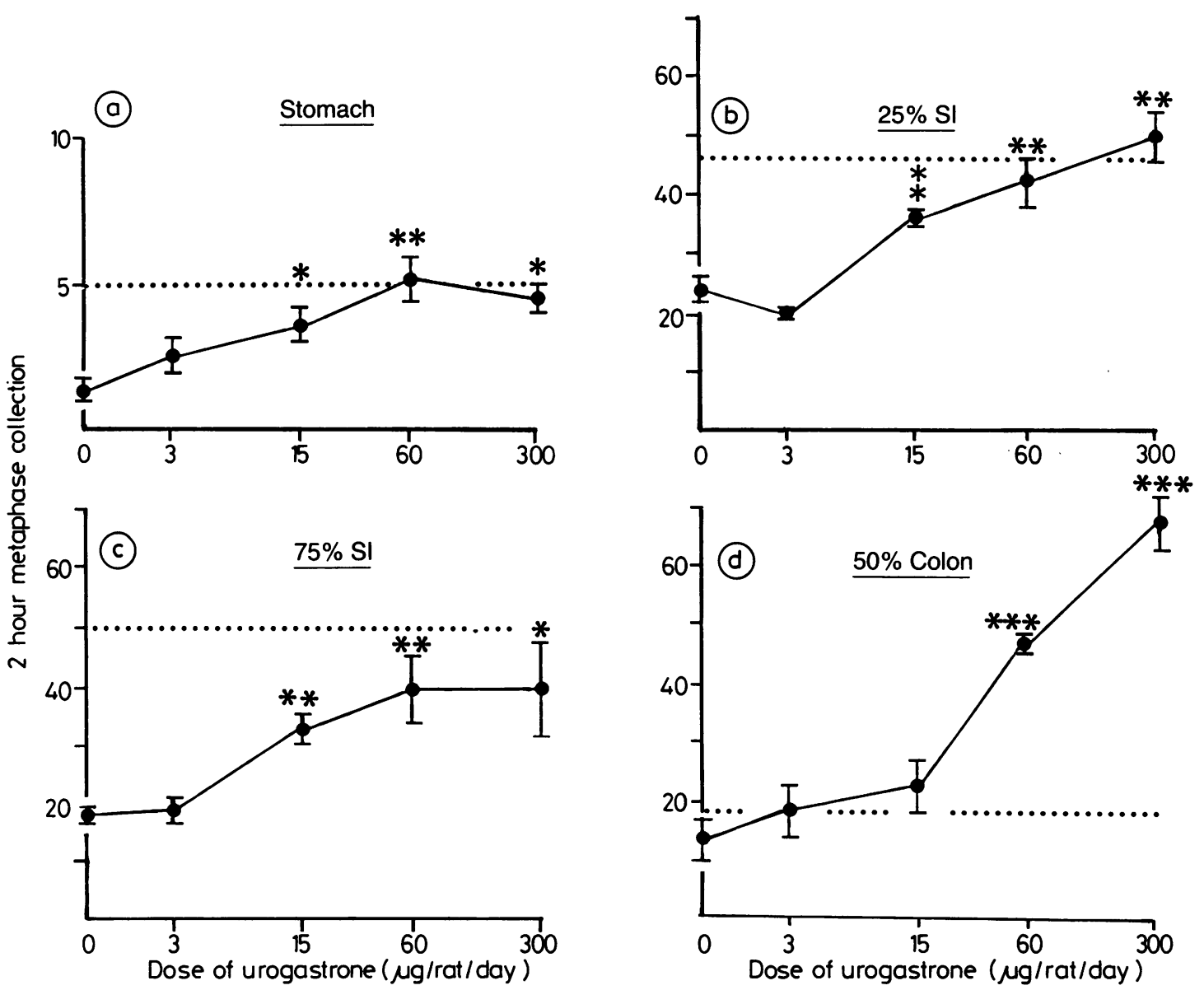

Fig. 2 Effects of 10 days intravenous infusion of various doses of urogastrone on 2 hour metaphase collection, mean value of 10 crypts or glands at the different sites of the gastrointestinal tract sampled. The dotted line shows the values obtained in orallyfed rats. There were four animals per group. ${ }^{*}=$ significantly higher than the TPN group $p<0 \cdot 05,{ }^{* *}=$ significantly higher than the TPN group $p<0 \cdot 01,{ }^{* * *}=$ significantly higher than the TPN group $p<0.001$.

just reached orally fed levels when given the highest dose of URO-EGF, the colonic values of the high dose group considerably exceeded the level seen in orally fed rats. ${ }^{31}$ The increase in the stomach value at the highest dose was $230 \%$, the mean increase in metaphases in the five small intestinal sites was $101 \pm$ $7.4 \%$ and the mean increase for the three colon sites was $427 \pm 20 \%$.

The rats in the $300 \mu \mathrm{g} / \mathrm{rat} / \mathrm{day}$ group were in a poor condition. No obvious pathology was apparent, but the rat's urine was bloody and glucose positive. The higher dose groups also had a reduced weight gain (Table 1) but the differences were not statistically significant.

The increase in metaphase collection was also reflected in the increase in measures of crypt and villus dimensions (Table 2), with $60 \mu \mathrm{g} / \mathrm{rat} / \mathrm{day}$ of
URO-EGF giving measures near those of orally fed rats.

\section{INTERVENTION TIME COURSE STUDY}

There was a general increase in tissue weights with time, and this was statistically significant (by analysis of variance) for the small intestine $(p<0.05)$ and for the colon $(p<0 \cdot 01)$. The effects of URO-EGF on the accumulation of arrested metaphases is shown in Figure 3 . There was a gradual increase in metaphases over the first 24 hours, becoming apparent 12 hours after the administration of URO-EGF in the stomach and small intestine; however there was no evidence of increased cell proliferation in the colon until 18 hours after the administration of URO-EGF. The rate of increase in arrested metaphases then levelled out after 24-50 hours. There was then an indication 
Table 1 Initial body weights, end weights and per cent weight increase (mean values $\pm S E$ )

\begin{tabular}{|c|c|c|c|c|c|c|}
\hline Group & $\begin{array}{l}\text { Start weight } \\
(g)\end{array}$ & \pm & $\begin{array}{l}\text { End weight } \\
(g)\end{array}$ & \pm & $\begin{array}{l}\text { Weight increase } \\
(\%)\end{array}$ & \pm \\
\hline \multicolumn{7}{|c|}{ Intravenous urogastrone dose response experiment } \\
\hline Control group & $186 \cdot 7$ & $3 \cdot 8$ & $188 \cdot 7$ & $2 \cdot 9$ & $1 \cdot 18$ & $2 \cdot 62$ \\
\hline $3 \mu \mathrm{g} / \mathrm{rat} / \mathrm{day}$ URO-EGF & $196 \cdot 3$ & $8 \cdot 0$ & $200 \cdot()$ & $5 \cdot 8$ & 2.05 & $1 \cdot 14$ \\
\hline $15 \mu \mathrm{g} / \mathrm{rat} / \mathrm{day}$ URO-EGF & $188 \cdot 8$ & $3 \cdot 2$ & $195 \cdot 1$ & $3 \cdot 4$ & $3 \cdot 37$ & 0.28 \\
\hline $60 \mu \mathrm{g} / \mathrm{rat} /$ day URO-EGF & $185 \cdot 0$ & $2 \cdot 9$ & $186 \cdot 0$ & $1 \cdot 6$ & 0.58 & $1 \cdot 14$ \\
\hline $300 \mu \mathrm{g} / \mathrm{rat} /$ day URO-EGF & $196 \cdot 3$ & $8 \cdot 0$ & $195 \cdot 0$ & $7 \cdot 5$ & -0.58 & $1 \cdot 38$ \\
\hline Intervention (time course) study & $201 \cdot 8$ & $1 \cdot 7$ & $208 \cdot 0$ & $2 \cdot 2$ & 3.09 & $0 \cdot 75$ \\
\hline \multicolumn{7}{|c|}{ Intragastric urogastrone crypt cell production rate experiment } \\
\hline TPN & 212.9 & $3 \cdot 8$ & $196 \cdot 6$ & $2 \cdot 8$ & $-7 \cdot 61$ & $1 \cdot 30$ \\
\hline TPN + URO-EGF & $215 \cdot 7$ & $4 \cdot 2$ & $204 \cdot 3$ & $2 \cdot 6$ & $-5 \cdot 21$ & 1.40 \\
\hline \multicolumn{7}{|c|}{ Intragastric urogastrone two hour metaphase collection experiment } \\
\hline TPN & $215 \cdot 8$ & $6 \cdot 3$ & $206 \cdot 0$ & $4 \cdot 0$ & $-4 \cdot 40$ & 1.79 \\
\hline TPN $+150 \mu \mathrm{g} / \mathrm{rat} /$ day URO-EGF & $207 \cdot 0$ & $3 \cdot 0$ & $211 \cdot 4$ & $4 \cdot 4$ & $2 \cdot 19$ & $2 \cdot 36$ \\
\hline TPN $+300 \mu \mathrm{g} / \mathrm{rat} /$ day URO-EGF & $216 \cdot 0$ & 5.4 & $213 \cdot 6$ & $6 \cdot 8$ & $-1 \cdot 00$ & $3 \cdot 00$ \\
\hline
\end{tabular}

of a further rise in arrested metaphases in the majority of sites studied.

INTRAGASTRIC STUDY

The daily intragastric infusion of $15 \mu \mathrm{g}$ of URO-EGF per rat had no effect on intestinal weight. The CCPR of the various intestinal sites is shown in Table 3 and although the CCPR appeared to be greater in the URO-EGF treated group, no significant differences were obtained. The increased CCPR (and variance) in the test group was caused by one animal which had raised levels of arrested metaphases; these were more than two standard deviations away from the arrest line of the other animals in most of the sites studied: the test and control groups were indistinguishable if the results from this animal were excluded.

Luminal administration of higher doses of UROEGF also had no effect on either the weight of the intestine or the two hour metaphase accumulation (Table 4).

Table 2 Effects of $60 \mu \mathrm{g} / \mathrm{rat} /$ day of urogastrone on the mean crypt and villus heights $(\mu \mathrm{m})$

\begin{tabular}{|c|c|c|c|c|}
\hline Site & \multicolumn{2}{|c|}{$T P N$ control \pm} & \multicolumn{2}{|l|}{ Test \pm} \\
\hline \multicolumn{5}{|c|}{$75 \%$ of the length of the small intestine } \\
\hline Villus height & $252 \cdot 4$ & $2 \cdot 48$ & $277 \cdot 6$ & $1 \cdot 65^{*}$ \\
\hline Crypt depth & $200 \cdot 1$ & $2 \cdot 49$ & 243.9 & $0.31 \dagger$ \\
\hline $\begin{array}{l}50 \% \text { of the length of the colon } \\
\text { Crypt depth }\end{array}$ & 199.0 & 1.79 & $246 \cdot 3$ & $1.30 \dagger$ \\
\hline
\end{tabular}

${ }^{*}=\mathrm{p}<0.01 ; \dagger=\mathrm{p}<0.001$. The rats were maintained parenterally with or without URO-EGF for 10 days. Three animals per group were studied and the results are presented $\pm \mathrm{SE}$.
Table 3 Effects of $15 \mu \mathrm{g} / \mathrm{rat} /$ day of urogastrone administered intragastrically on the crypt cell production rates of the different sites in the gastrointestinal tract

\begin{tabular}{|c|c|c|c|c|}
\hline \multirow{2}{*}{$\begin{array}{l}\text { Site } \\
\text { Stomach }\end{array}$} & \multicolumn{2}{|c|}{$\begin{array}{l}T P N \\
\text { controls } \\
\pm\end{array}$} & \multicolumn{2}{|c|}{$\begin{array}{l}T P N+ \\
U R O-E G F \\
\pm\end{array}$} \\
\hline & 0.59 & $0 \cdot 24$ & $0 \cdot 38$ & 0.56 \\
\hline $10 \%$ of the length of the small intestine & $7 \cdot 50$ & 1.58 & $11 \cdot 03$ & $4 \cdot 33$ \\
\hline $50 \%$ of the length of the small intestinc & $5 \cdot 63$ & $1 \cdot 35$ & $11 \cdot 25$ & $2 \cdot 53$ \\
\hline $90 \%$ of the length of the small intestine & $7 \cdot 28$ & $0 \cdot 83$ & $13 \cdot 01$ & $4 \cdot 53$ \\
\hline $50 \%$ of the length of the colon & $2 \cdot 92$ & 1.44 & $5 \cdot 00$ & 1.08 \\
\hline $90 \%$ of the length of the colon & $3 \cdot 60$ & $2 \cdot 78$ & $2 \cdot 89$ & $5 \cdot 01$ \\
\hline
\end{tabular}

The rats were on their respective treatments for 10 days. The crypt cell production rate is expressed as cells produced per crypt per hour. There were seven animals per group.

Table 4 Effects of $150 \mu \mathrm{g} / \mathrm{rat} /$ day urogastrone and $300 \mu \mathrm{g} / \mathrm{rat} /$ day urogastrone on the two hour collection of metaphases

\begin{tabular}{|c|c|c|c|c|c|c|}
\hline \multirow{7}{*}{$\begin{array}{l}\text { Site } \\
\text { Stomach } \\
10 \% \text { of the length of } \\
\text { the small intestinc } \\
50 \% \text { of the length of } \\
\text { the small intestinc } \\
90 \% \text { of the length of } \\
\text { the small intestinc } \\
50 \% \text { of the length of } \\
\text { the colon } \\
90 \% \text { of the length of } \\
\text { the colon }\end{array}$} & \multicolumn{2}{|l|}{$T P N$} & \multicolumn{2}{|c|}{$\begin{array}{l}T P N+ \\
\text { I5O } \mu g \\
\text { URO-EGF }\end{array}$} & \multicolumn{2}{|c|}{$\begin{array}{l}T P N+ \\
300 \mu g \\
U R O-E G F\end{array}$} \\
\hline & $1 \cdot 13$ & $0 \cdot 06$ & $2 \cdot 74$ & $1 \cdot(0)$ & 0.52 & (). 13 \\
\hline & $24 \cdot 7$ & $2 \cdot 4$ & $27 \cdot 2$ & $6 \cdot 6$ & $28 \cdot 6$ & $2 \cdot 8$ \\
\hline & $24 \cdot 0$ & 3.9 & $20 \cdot 5$ & $4 \cdot 3$ & $29 \cdot 5$ & $2 \cdot 2$ \\
\hline & $23 \cdot 8$ & 1.9 & $23 \cdot 3$ & $6 \cdot 1$ & $21 \cdot 5$ & $1 \cdot 3$ \\
\hline & $15 \cdot 1$ & $3 \cdot 83$ & $7 \cdot 3$ & 1.95 & $11 \cdot 8$ & $4 \cdot 8$ \\
\hline & $13 \cdot 8$ & $3 \cdot 80$ & $5 \cdot 8$ & $2 \cdot 2$ & $7 \cdot 2$ & $2 \cdot 6$ \\
\hline
\end{tabular}

The treatments lasted for 10 days. There were four animals in the control group, five in the $150 \mu \mathrm{g} / \mathrm{rat} /$ day group and four in the $3(\%)$ $\mu \mathrm{g} r a t / d a y$ group. 

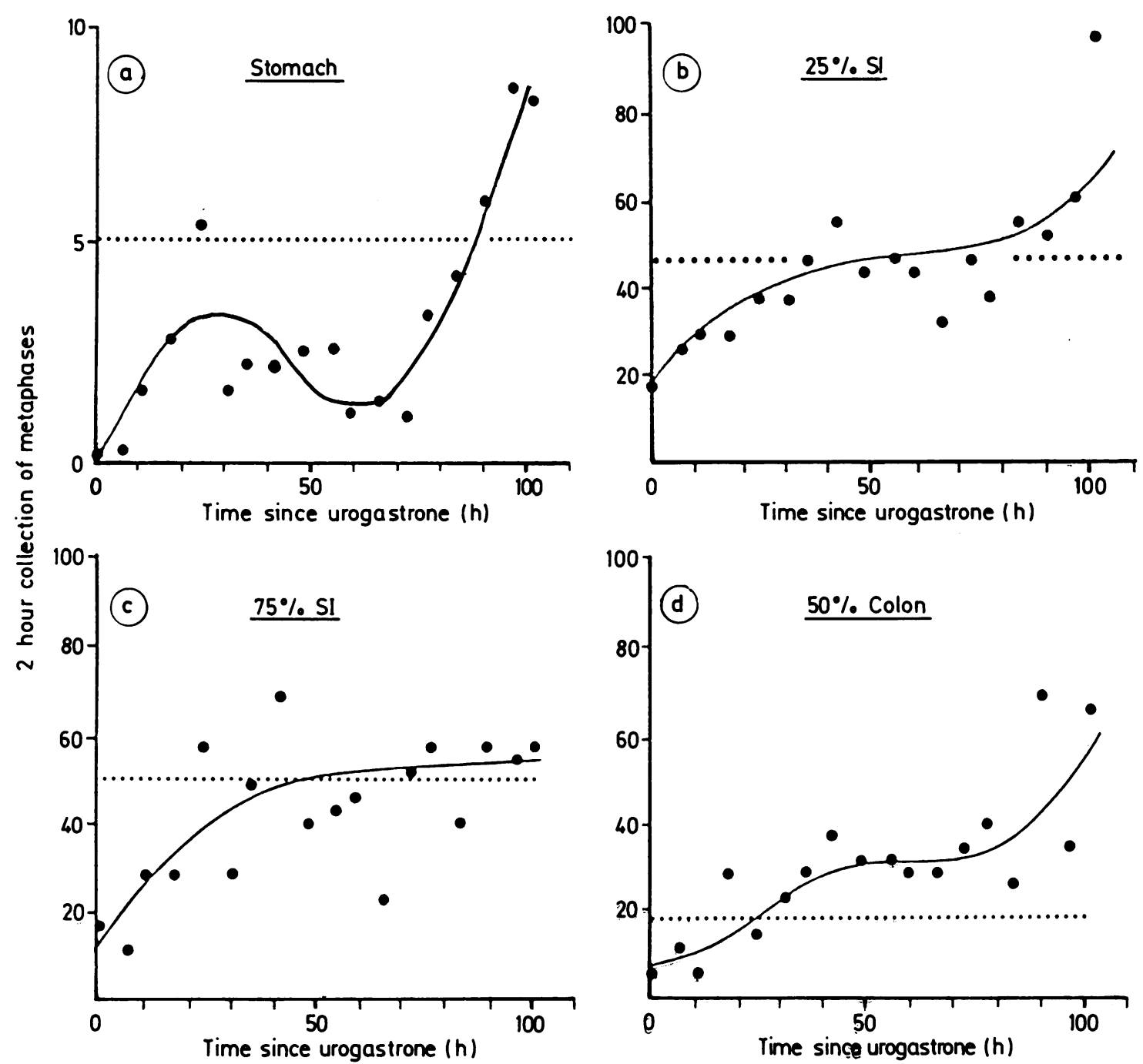

Fig. 3 Two hour metaphase collection (mean value for 10 crypts ar glands) at various times after the administration of urogastrone in the different sites along the gastrointestinal tract sampled. The rats were maintained by TPN for four days before the infusion of $60 \mu \mathrm{g} / \mathrm{rat} / \mathrm{day}$ of urogastrone. Lines were fitted by eye. The dotted line shows the values obtained in orally fed rats.

\section{Discussion}

The results of the present study show that URO-EGF will stimulate intestinal epithelial cell proliferation and growth in TPN rats in all sites of the gastrointestinal tract in a dose dependent manner, with the most marked effects being observed in the stomach and colon. We have previously shown that a relatively low dose, which should not inhibit acid secretion, significantly increased crypt cell production throughout the intestine, with the CCPR's of the stomach and colon increasing to the levels observed in orally fed rats. ${ }^{31}$

$\beta$-urogastrone/human epidermal growth factor was also effective in stimulating proliferation once hypoplasia had become established. The time course of events after this 'intervention' are described. The intragastric infusion of URO-EGF had no effect on intestinal weight or CCPR at the same dose that had significant effects throughout the intestine when 
given intravenously, nor did it have any effect on intestinal weight or metaphase collection at higher doses.

Tissue wet weight is only a crude measure of intestinal hyperplasia, but when it is combined with increased metaphase collection can confirm that these increases in proliferation are linked to hyperplasia. We have also shown that these weight changes are accompanied by similar, significant changes in villus height and crypt depth (Table 2).

The intestinal atrophy associated with TPN should occur within a few days ${ }^{27}$ and the similarity between the two hour metaphase accumulations after four days of TPN in the intervention study and after 10 days TPN in the other studies, and the high degree of comparability between the various (TPN) control groups substantiates this; thus the TPN control rats should have been in a 'steady state' of reduced intestinal proliferation. The rats maintained on TPN showed a slight gain in body weight despite the surgery, loss of digesta and gut tissue. $\beta$-urogastrone/ human epidermal growth factor treated rats showed a greater weight gain which could be explained by the increase in gut weight. The rats dosed intragastrically all lost some weight but no significant differences between groups was noted.

The dose response studies showed that there was a log linear relationship between dose of URO-EGF and proliferation. The response of the different sites varied with the colon showing the most pronounced response increase. One could speculate that this reflects variations in receptor number among the cell populations.

The increase in proliferation in the intervention study was seen after 12 hours in the stomach and small intestine but only after 18 hours in the colon. Similar differences in the time course of proliferative increase have been observed in the intestine of starved mice after refeeding,${ }^{35}$ which implied that the delay in colonic response was the consequence of the greater time taken for digesta to reach the colon; however, the present results suggest that this delay reflects some inherent difference between the colon and the stomach-small intestine. The time taken for a proliferative response is a function of the cell cycle time of the tissue involved, ${ }^{36}$ thus the present result could be a reflection of the longer cycle time of the colonocyte. ${ }^{37}$

The exact shape of time course curves is obscured by the variability of the data. The increase in proliferation in some intestinal sites appeared to tail off. The proliferation in other sites did not appear to do so, and in some of these sites proliferation seemed to be increasing again at the end of the investigation.

The intragastric infusion of various doses of UROEGF had no significant effect on intestinal weights,
CCPR or two hour metaphase collection. This is in conflict with the results of Dembinski et al ${ }^{22}$ who reported a trophic response of the stomach and duodenum when $30 \mu \mathrm{g} / \mathrm{kg} /$ day of URO-EGF was given intragastrically to rats. Although URO-EGF is taken up by the digestive tract in the neonate and weanling rat, ${ }^{38}$ recent evidence suggests that it is not absorbed in the adult gut. ${ }^{39}{ }^{+11}$ It has also been reported that intragastric URO-EGF has a cytoprotective action in the damaged gastric mucosa ${ }^{16}$; however, the intestine was not damaged in this study. Another report suggests intragastric URO-EGF stimulates mucosal repair at doses that do not affect gastric acid secretion. ${ }^{38}$ This effect is observed within three to four hours after administration, which suggests that it may be caused by the stimulation of protective compounds, such as glucosaminoglycans and cell surface glycoproteins with subsequent alterations in cell membrane properties.

The mechanisms or significance of the in vivo trophic action of URO-EGF are as yet unknown. Gastrointestinal epithelial cells possess URO-EGF receptors ${ }^{145}$ and the lack of response to luminal URO-EGF would suggest that they are located on the baso-lateral side of the enterocyte. This action may either occur through a systemic mechanism or through the local release of URO-EGF from sites other than the salivary or Brunners glands. It is also possible that these actions are mediated by another hormone or factor. Several other humoral factors, especially enteroglucagon ${ }^{24}$ may also have a role to play in intestinal adaptation and their actions and interactions with URO-EGF have still as yet to be elucidated.

The trophic response of the gastrointestinal tract to URO-EGF could open up several avenues for the understanding of intestinal growth control and for the treatment of intestinal disease and dysfunction. The cytoprotective role of URO-EGF has already been advocated ${ }^{16}$ and the present results in the TPN rat would suggest that URO-EGF may be of use in the prevention or reversal of the atrophy associated with intravenous alimentation in the human. A human infant with a congenital malabsorption syndrome requiring intravenous alimentation has recently been treated with recombinant URO-EGF and intestinal proliferation increased significantly. ${ }^{41}$

The present study has confirmed that TPN is associated with profound intestinal hypoplasia resulting in a new 'steady state'. We have also shown that URO-EGF was effective in reducing this hypoproliferative state when given either during the initiation of TPN associated hypoplasia (maintenance) or when hypoplasia had become established (intervention), suggesting that URO-EGF could play 
an important role as a trophic factor in the maintenance of epithelial proliferation in the gastrointestinal tract.

We thank the Cancer Research Campaign for financial assistance. This study was presented in part at the British Society for Gastroenterology meeting in Liverpool 1984.

\section{References}

1 Heitz PU, Kasper M, Van Noorden S, Polak JM, Gregory H, Pearse AGE. Immunohistochemical localisation of urogastrone to human duodenal and submandibular glands. Gut 1978; 19: 408-13.

2 Olsen PS, Nexo E. Quantitation of epidermal growth factor in the rat: Identification and partial characterisation of duodenal EGF. Scand J Gastroenterol 1983; 18: $771-6$.

3 Gregory $\mathbf{H}$. Isolation and structure of urogastrone and its relationship to epidermal growth factor. Nature (Lond) 1975; 257: 325-7.

4 Carpenter G, Cohen S. Epidermal growth factor. Ann Rev Biochem 1979; 48: 193-216.

5 Carpenter G. Epidermal growth factor. In: Baserga R, ed. Tissue growth factors. Berlin: Springer-Verlag, 1981: 89-123.

6 Malo C, Menard D. Influence of epidermal growth factor on the development of suckling mouse intestinal mucosa. Gastroenterology 1982; 83: 28-35.

7 Oka Y, Ghrisan FK, Greene HL, Orth DN. Effect of mouse epidermal growth factor/urogastrone on functional maturation of rat intestine. Endocrinology 1983; 112: $940-4$.

8 Calvert R, Beaulieu JF, Menard D. Epidermal growth factor EGF: accelerates the maturation of foetal mouse intestinal mucosa in utero. Experientia 1982; 38: 1096.

9 Feldman EJ, Aures D, Grossman MI. Epidermal growth factor stimulates ornithine decarboxylase activity in the digestive tract of the mouse. Proc Soc Exp Biol Med 1978; 159: 400-2.

10 Luk GD, Marten LJ, Baylin SB. Ornithine decarboxylase is important in intestinal mucosal maturation and recovery from injury in rats. Science 1980; 210: 195-8.

11 Carpenter G. Epidermal growth factor is a major growth promoting agent in human milk. Science 1980; 210: 198-9.

12 Li AKC, Schattenkerk ME, Huffman RG, Ross JS, Malt RA. Hypersecretion of submandibular saliva in male mice: trophic response in small intestine. Gastroenterology 1983; 84: 949-55.

13 Olsen PS, Poulsen SS, Kirkegaard P, Nexo E. Role of submandibular saliva and epidermal growth factor in gastric cytoprotection. Gastroenterology 1984; 87: 103-8.

14 Forgue-Lafitte ME, Laburthe $M$, Chambblier MC, Moody AJ, Rosselin G. Demonstration of specific receptors for EGF/urogastrone in isolated rat intestinal epithelial cells. FEBS Lett 1980; 114: 243-6.

15 St Hilaire RJ, Gospodarowicz D, Kim YS. Epidermal growth factor: effect on the growth of a human colon adenocarcinoma cell line. Gastroenterology 1981; 78: 1271.

16 Kirkegaard P, Olsen PS, Poulsen SS, Nexo E. Epidermal growth factor inhibits Cysteamine-induced duodenal ulcers. Gastroenterology 1983; 85: 1277-83.

17 Bower JM, Camble R, Gregory H, Gerring EL, Willshire IR. The inhibition of gastric acid secretion by epidermal growth factor. Experientia 1975; 31: 825-6.

18 Schieving LA, Yeh YC, Scheiving LE. Circadian phasedependant stimulatory effects of epidermal growth factor on deoxyribonucleic acid synthesis in the tongue, oesophagus, and stomach of the adult male mouse. Endocrinology 1979; 105: 1475-80.

19 Schieving LA, Yeh YC, Tsai TH, Scheiving LE. Circadian phase-dependant stimulatory effects of epidermal growth factor on deoxyribonucleic acid synthesis in the duodenum, jejunum, ileum, caecum, colon and rectum of the adult male mouse. Endocrinology 1980; 106: 1498-503.

20 Johnson LR, Guthrie PD. Stimulation of rat oxyntic gland mucosal growth by epidermal growth factor. $A m J$ Physiol 1980; 238: G45-G49.

21 Chabot JG, Paget N, Hugon JS. Effects of epidermal growth factor EGF: on adult mouse small intestine in vivo and in organ culture. Comp Biochem Physiol pt A 1983; 74: 247-52.

22 Dembinski A, Gregory H, Konturek SJ, Polanski M. Trophic action of epidermal growth factor on the pancreas and gastroduodenal mucosa in rats. $J$ Physiol (Lond) 1982; 325: 35-42.

23 Majumdar APN. Postnatal undernutrition: effects of epidermal growth factor on growth and function of gastrointestinal tract in rats. $J$ Pediatr Gastroenterol Nutr 1984; 3: 618-25.

24 Al-Muhhtar MYT, Polak JM, Bloom SR, Wright NA. The search for appropriate measurements of proliferative and morphological status in studies on intestinal adaptation. In: Robinson JWL, Dowling RH, Reicken EO, eds. Intestinal adaptation II. Lancaster: MTP Press Ltd, 1982: 3-25.

25 Goodlad RA, Wright NA. Quantitative studies on epithelial replacement in the gut. In: Titchen TA, ed. Techniques in the life sciences. Techniques in digestive physiology. Vol P2. Dublin: Elsevier Biomedical Press, 1982: 212/1-23.

26 Al-Nafussi A, Wright NA. The effect of epidermal growth factor EGF: on cell proliferation of the gastrointestinal mucosa of rodents. Virchows Arch [Cell Pathol] 1982; 40: 63-9.

27 Hughes CA, Dowling RH. Speed of onset of adaptive mucosal hypoplasia and hypofunction in the intestine of parenterally fed rats. Clin Sci 1980; 59: 317-27.

28 Robinson JWL, Dowling RH, Reicken EO, eds. Intestinal adaptation II. Lancaster: MTP Press, 1982.

29 Wright NA, Alison M. The biology of epithelial cell populations. Vol 2. Oxford: Clarendon Press, 1984: 842-68.

30 Goodlad RA, Wilson TG, Lenton W, Wright NA, Gregory H, McCullagh KG. Urogastrone-Epidermal growth factor is trophic to the intestinal epithelium of parenterally fed rats. Experientia 1985; 41: 1161-3.

31 Smith J, Cook E, Fotheringham I, et al. Chemical 
synthesis and cloning of a gene for human $\beta$-urogastrone. Nucleic Acid Res 1982; 10: 4467-82.

32 Franklin TJ, Gregory H, Morris WP. Acceleration of wound healing by recombinant urogastrone (epidermal growth factor). J Lab Clin Med 1986. (In press)

33 Gregory $\mathrm{H}$, Holmes JE, Willshire IR. Urogastrone levels in the urine of normal adult humans. J Clin Endocrinol Metab 1977; 45: 668-72.

34 Perheentupa J, Lakshmanan J, Hoath SB, et al. Epidermal growth factor measurements in mouse plasma: method, ontology and sex difference. Am J Physiol 1985; 248: E391-E6.

35 Goodlad RA, Wright NA. The effects of starvation and refeeding on intestinal cell proliferation in the mouse. Virchows Arch B 1984; 45: 63-73.

36 Brooks RF, Bennett DG, Smith JA. Mammalian cell cycles need two random transitions. Cell 1980; 19: 493-504.
37 Hagemann RF, Stragand JJ. Fasting and refeeding: Kinetic response of jejunum, ileum and colon. Cell Tiss Kinet 1977; 10: 3-14.

38 Thornburg W, Matrisian L, Magun B, Koldovsky O. Gastrointestinal absorption of epidermal growth factor in suckling rats. Am J Physiol 1984; 246: G80-G85.

39 Skov Olsen P, Poulsen SS, Kirkegaard P, Nexo E. Does urinary epidermal growth factor EGF: originate from the gastrointestinal tract. Dig Dis Sci 1984: 29: 615.

40 Skov Olsen P, Poulsen SS, Kirkegaard P, Nexo E. Role of submandibular saliva and epidermal growth factor in gastric cytoprotection. Gastroenterology 1984; 87: 103-8.

41 Walker-Smith JA, Phillips AD, Walford N, et al. Intravenous epidermal growth factor/urogastrone increases small intestinal cell proliferation in congenital microvillous atrophy. Lancet 1985; ii: 1239-40. 